\title{
Prejudice and discrimination in the everyday life of same-sex couples raising children
}

\author{
Preconceito e discriminação no cotidiano de \\ casais homossexuais com filhos
}

\author{
Mário Augusto TOMBOLATO ${ }^{1}$ \\ ORCID iD 0000-0002-2486-2671 \\ Ana Cláudia Bortolozzi MAIA ${ }^{2}$ \\ ORCID iD 0000-0003-4796-5451 \\ Anna Paula UZIEL 3 \\ ORCID iD 0000-0001-7807-3910 \\ Manoel Antônio dos SANTOS ${ }^{1}$ \\ ORCID iD 0000-0001-8214-7767
}

\begin{abstract}
The present study investigated the experiences of prejudice and discrimination in the everyday lives of five same-sex couples raising children. Data were collected using a questionnaire and an interview and were analyzed by thematic analysis. Participants attributed meanings to their experiences of being homoparental families: they assumed their social role as they managed to develop their own conjugality and parental projects in the struggle within a social context permeated by the hegemony of heteronormative values. The participants experienced prejudice related to their lifestyle and attained parenthood status, challenging social norms and gender stereotypes. However, it was also found that attitudes of willingness and perseverance in their fight for their rights proved to be protective measures against prejudice and social intolerance. A limited number of studies have examined the prejudice and discrimination towards same-sex families in Brazil; therefore, there is a need for greater visibility and further discussion about this phenomenon.
\end{abstract}

Keywords: Family; Homosexuality; Parents; Prejudice.

\section{Resumo}

Este estudo investigou as vivências de manifestações de preconceito e discriminação no cotidiano de cinco casais homossexuais com filhos. Os dados coletados por questionário e entrevista foram analisados pela técnica de análise temática. Os participantes atribuíram significados às suas vivências enquanto famílias homoparentais: assumiram o

1 Universidade de São Paulo, Faculdade de Filosofia, Ciências e Letras de Ribeirão Preto, Departamento de Psicologia. Av. Bandeirantes, 3900, Monte Alegre, 14040-901, Ribeirão Preto, SP, Brasil. Correspondência para/Correspondence to: M.A. TOMBOLATO. E-mail: <marioaugt@hotmail.com>.

2 Universidade Estadual Paulista "Júlio de Mesquita Filho", Faculdade de Ciências, Departamento de Psicologia. Bauru, SP, Brasil.

3 Universidade do Estado do Rio de Janeiro, Instituto de Psicologia, Departamento de Psicologia Social e Institucional. Rio de Janeiro, RJ, Brasil.

Support: Fundação de Amparo à Pesquisa do Estado de São Paulo (Process 12/13570-7 and 15/09173-0).

$\mathbf{\nabla} \mathbf{\nabla} \boldsymbol{\nabla}$

Como citar este artigo/How to cite this article

Tombolato, M. A., Maia, A. C. B., Uziel, A. P., \& Santos, M. A. (2018). Prejudice and discrimination in the everyday life of same-sex couples raising children. Estudos de Psicologia (Campinas), 35(1), 111-122. https://doi.org/10.1590/1982-027520180001000011 
protagonismo social ao conseguirem gerar seus projetos de conjugalidade, maternidade e paternidade no embate com o contexto social permeado pela hegemonia dos valores da heteronormatividade. Os preconceitos vivenciados pelos participantes foram dirigidos aos seus modos de viver e por assumirem a parentalidade, desafiando convenções sociais e estereótipos de gênero. Entretanto, também se observou que atitudes como disposição e perseverança na luta pelos seus direitos demonstraram ser medidas protetoras contra o preconceito e a intolerância social. Um limitado número de estudos tem avançado na temática do preconceito e da discriminação voltados à família homoparental brasileira; logo, é inadiável dar visibilidade à discussão desse fenômeno.

Palavras-chave: Familia; Homossexualidade; Pais; Preconceito.

Considering the sociocultural and political trajectory of family constitution over time, there has been an emergence of new family configurations different from that of the traditional family. One of them is the arrangement characterized by same-sex couples and their children (Golombok, 2015; Grossi, Uziel, \& Mello, 2007). This topic is relevant to the current scenario of today's society, permeated by many people who consider legitimate only one type of family arrangement, treating others as peripheral or illegitimate. When social interaction is governed by the principle of right to equality before the law, it is worth highlighting the diversity of families in our society, urging us to always use the noun "families", i.e., in its plural form. Thus, more studies are necessary to give greater visibility to these families in the national context since it is of fundamental importance to understand their experiences and participation in the private and social spheres (Goldberg \& Gartrell, 2014).

Relationships between persons of the same sex - known today as homosexuality - have been established in different ways in societies throughout the history of mankind (Farias \& Maia, 2009; Zambrano, 2006). According to Vieira (2011), homosexuality is understood as one of the variants within the human sexual panorama. The current conception of homosexuality results from struggles and victories achieved over time, but the author state that "there are still opposing moral and especially religious discourses, hindering the exercise or enjoyment of any rights of individuals who recognize and identify themselves as homosexuals" (Vieira, 2011 p. 16).

In addition to these historical, cultural, and political processes involving changes regarding homosexuality, there is another relevant theme intertwined with this context, which concerns conceptions of family. According to Ariès (1986), the current conception of family was developed in Europe in the mid 18th century. For example, marriage, previously defined as an arrangement between two families aiming at guaranteeing family patrimony and/or lineage ties, has become an alliance with the purpose of conciliating affective and social interests, based thereafter on love, sense of happiness, and individual freedom. Procreation used to be considered the culminating point of marriage, and parents were responsible not only for biological reproduction, but also and especially for their children upbringing, education, and care, including the transmission of values, customs, and social traditions (Badinter, 1985).

Historical changes have continuously broadened the meanings of the term family. The resulting family arrangements should not necessarily be understood as arising from a crisis in the family institution, but rather as reflections of recurrent changes in society (Oliveira, 2011; Roudinesco, 2003). Therefore, the notion of family can be formed from a range of conceptions. However, as previously mentioned, such conceptions will always be under constant transformation.

In the midst of such changes, there is what some authors call homoparental (same-sex) families. Homoparentality (same-sex parenting) is an English neologism for the French term homoparentalité, which was coined in 1996/1997 by the Association of gay and lesbian parents and future parents (Roudinesco, 2003). It concerns the uniqueness of homosexual parenting, i.e., the situation in which at least one adult who self-identifies as a homosexual is (or intends to be) the father or mother of at least one child (Zambrano, 2006). 
Homoparentality or same-sex parenting, as a denomination given to a particular family arrangement, can be understood by considering the socio-cultural context of struggles and victories for the rights to achieve recognition and respect (Rodriguez, 2012). In 2011, the Federal Supreme Court of Brazil recognized the domestic partnership for same-sex couples, legitimizing them as a family entity. Two years later, in 2013, during the 169th Plenary Session of the National Council of Justice $(\mathrm{CNJ})$, the council passed a resolution to allow civil union for same-sex couples or the conversion of domestic partnership into marriage (Supremo Tribunal Federal, 2013). These events represent a milestone victory for Lesbian, Gay, Bisexual, and Transgender (LGBT) rights. In the everyday life of same-sex families, this means a legal protection that can contribute to change the way we look at these family configurations, to break down prejudice and discrimination, and to deter violence (Grossi et al., 2007; Oliveira, 2011).

Studies in various contexts have shown that families formed by same-sex couples have characteristics and functions that are common to any other type of family configuration: the responsibilities and difficulties involved in the upbringing of and caring for the child; the planning of financial and daily routines; and the provision of entertainment, among others (Almeida, 2012; Goldberg \& Gartrell, 2014; Golombok et al., 2014; Golombok, 2015; Martinez \& Barbieri, 2011; Uziel, 2007). Moreover, studies addressing the Brazilian scenario have shown that, unlike families formed by cisgender and heterosexual individuals, this family configuration has led individuals to face challenges and discrimination in diverse social contexts (Almeida, 2012; Corrêa, 2012; Farias \& Maia, 2009; Lira, Morais, \& Boris, 2016; Toledo, 2008; Uziel, 2007).

Moscheta $(2004$, p.6) said "the homosexual relationship is established through continuous dialogue with social contexts, which, due to prejudice and discrimination, hindering and segregating marital experience, leading to anguish". Although same-sex families "have gained social visibility in recent years, they have also been targets of attacks and their legitimacy and social citizenship have been challenged by institutions of great importance in everyday life, such as the Church and the legislative and judicial powers" (Toledo, 2008, p.9). Such resistance is related to expressions of homophobia, which, according to Borrillo (2009), means "hostile attitudes towards homosexuals" (p.15) expressed through discriminatory judgments, verbal or physical aggressions, and symbolic violence. In other words, they are prejudiced expressions present in the everyday life of a heteronormative society which defines homosexual people as "deviant" in different social spaces, including family structures. In Brazil, there is no specific law to punish expressions of prejudice and discrimination on grounds of sexual orientation.

In 2011, for the first time, the Brazilian Federal Government conducted a systematic survey of data on homophobic violence in the country (Secretaria de Direitos Humanos, 2012), identifying a total of 310 homicides with LGBT victims. In the following year, 2012, another survey revealed an increase in the number of cases by $11.51 \%$, reaching 329 homicides (Secretaria de Direitos Humanos, 2013). The available official statistics are alarming, but they probably underestimate the true magnitude of the problem due to underreporting and difficulties in characterizing homophobia motivated incidents and crimes.

Furthermore, there are few national studies on the prevention and/or intervention programs due to incipient scientific production in this field, which hinders the formulation of specific public policies. We believe that further studies are needed to contribute to the training and education in Psychology, and for health, education, and law professionals, as well as others in related areas. Based on the aforementioned discussions and the literature review conducted, the objective of this study was to investigate the instances of prejudice and discrimination in the everyday lives of same-sex couples raising children.

\section{Method}

A qualitative study was carried out based on the "universe of meanings, motives, aspirations, 
beliefs, values, and attitudes" (Minayo, 2010, p.21), which contributes to the understanding of how people interpret and make sense of their experiences and the world in which they live (Bogdan \& Biklen, 1994).

\section{Participants}

Five same-sex couples (ten people) of both sexes raising children participated in this study. Inclusion criteria included: same-sex couples who lived with their children - biological and/or adopted - who had been placed with the family for at least two years. Table 1 shows the main characteristics of the couples included in the study.

Table 1 shows that the level of education of most of the participants was high (at least incomplete higher education) and that all of them had paid jobs. Data were organized according to the order in which they were collected in 2013.

Names of Brazilian painters were used in place of the participants' real names, and names of Brazilian writers were used in place of their children's names. All other proper names, places, and certain characteristics were replaced or omitted to maintain confidentiality and preserve the identity of the participants.

\section{Instruments}

Two instruments were used in the present study: Questionário de Perfil Socioeconômico de Famílias Homoparentais (Socioeconomic Questionnaire for Same-sex Couples with Children)

Table 1

Sociodemographic and family characteristics of study participants

\begin{tabular}{|c|c|c|c|c|c|c|c|c|}
\hline Couple & Name & $\begin{array}{c}\text { Age } \\
\text { (years) }\end{array}$ & $\begin{array}{c}\text { Level of } \\
\text { education }\end{array}$ & $\begin{array}{c}\text { Monthly } \\
\text { household } \\
\text { income }(R \$)\end{array}$ & $\begin{array}{l}\text { Relationship } \\
\text { length }\end{array}$ & Child name & $\begin{array}{l}\text { Child } \\
\text { age }\end{array}$ & Parenting choice \\
\hline 1 Female & $\begin{array}{l}\text { Tarsila do } \\
\text { Amaral } \\
\text { Adriana } \\
\text { Varejão }\end{array}$ & 27 & $\begin{array}{c}\text { Graduate } \\
\text { Education } \\
\text { Higher } \\
\text { Education }\end{array}$ & $6,850.00$ & $\begin{array}{c}3 \text { years and } \\
2 \text { months }\end{array}$ & $\begin{array}{c}\text { Nísia } \\
\text { Floresta }\end{array}$ & $\begin{array}{c}2 \text { years } 6 \\
\text { months old }\end{array}$ & Adoption \\
\hline 2 Male & $\begin{array}{c}\text { Pedro Américo } \\
\text { Heitor dos } \\
\text { Prazeres }\end{array}$ & 49 & $\begin{array}{c}\text { Higher } \\
\text { Education } \\
\text { Incomplete } \\
\text { Higher Education }\end{array}$ & $5,000.00$ & $\begin{array}{l}20 \text { years } \\
8 \text { months }\end{array}$ & $\begin{array}{l}\text { Adélia } \\
\text { Prado/Lara } \\
\text { de Lemos }\end{array}$ & $\begin{array}{c}11 \text { years } \\
\text { old/2 years } 4 \\
\text { months old }\end{array}$ & Adoption \\
\hline 3 Female & Anita Malfatti & 46 & $\begin{array}{c}\text { Technical } \\
\text { School Higher } \\
\text { Education } \\
\text { (Undergraduate } \\
\text { student) }\end{array}$ & $6,200.00$ & 18 years & $\begin{array}{l}\text { Lima } \\
\text { Barreto }\end{array}$ & $\begin{array}{c}15 \text { years } \\
\text { old }\end{array}$ & $\begin{array}{c}\text { Artificial } \\
\text { insemination }\end{array}$ \\
\hline & Ione Saldanha & 50 & Higher Education & & & & & \\
\hline 4 Female & $\begin{array}{l}\text { Isabelle } \\
\text { Tuchband } \\
\text { Beatriz } \\
\text { Milhazes }\end{array}$ & 28 & $\begin{array}{l}\text { Technical School } \\
\text { Incomplete } \\
\text { Higher Education }\end{array}$ & $2,050.00$ & 7 years & $\begin{array}{c}\text { Maria } \\
\text { Clara } \\
\text { Machado }\end{array}$ & 11 years old & $\begin{array}{c}\text { Child from } \\
\text { Beatriz's previous } \\
\text { heterosexual } \\
\text { relationship }\end{array}$ \\
\hline 5 Male & $\begin{array}{l}\text { Candido } \\
\text { Portinari } \\
\text { Francisco } \\
\text { Rebolo }\end{array}$ & 26 & $\begin{array}{c}\text { Incomplete } \\
\text { Higher } \\
\text { Education } \\
\text { Higher Education }\end{array}$ & $3,900.00$ & $\begin{array}{c}5 \text { years } \\
7 \text { months }\end{array}$ & $\begin{array}{c}\text { Rachel de } \\
\text { Queiroz }\end{array}$ & 2 years old & Adoption \\
\hline
\end{tabular}


and a semi-structured interview, Conhecendo as Familias Homoparentais (Getting to Know Samesex Families). These instruments were developed by the authors based on the information obtained from other related studies. They were submitted to a panel of three experts (PhD. Professors), who assessed the relevance and suitability of the questions proposed; changes were made following the panel's recommendations. A pilot interview was conducted to test the suitability of the instruments based on the research objectives.

The Questionário de Perfil Socioeconômico de Familias Homoparentais is composed of open and closed questions designed to collect couples' personal data and information on socioeconomic characteristics of same-sex families. The interview guide Conhecendo as Familias Homoparentais is composed of 19 open questions, which were answered jointly by the couple, addressing their relationship history, family of origin, parenting choices; family routine, and religion among others. In the present study, priority was given to questions about relationships between the families and society and/or community and experiences of prejudice.

\section{Procedures}

This study was carried out in compliance with the guidelines for research involving human participants (Ministério da Saúde, 2012). It was approved by the Brazil/CEP Platform (Research Ethics Committee) in April 2013 (CAAE: 06439812.0.0000.5398/\#254.353). All participants read and signed the Informed Consent Form.

Potential participants were identified and invited to participate in the study using internet search engines, contact with other researchers working on this topic and members of their personal network who know or could nominate same-sex families, and referrals from initial participants using the "snowball" sampling technique (Biernacki \& Waldorf, 1981).

In order to meet the study objectives, both members of the couple were interviewed together. A similar procedure was observed in other studies involving homosexual/same-sex couples (Almeida, 2012; Rodriguez, 2012). Data were collected from the participating couples by a researcher in their homes, except for one of them, who met with the researcher in a commercial establishment. The interviews ranged in length from 1 hour 16 minutes to 2 hours 5 minutes. They were audio-recorded and transcribed in their entirety.

The data were analyzed using the 6-phase thematic analysis approach, according to Braun and Clarke (2006): (a) familiarizing yourself with your data, (b) generating initial codes, (c) searching for themes, (d) reviewing themes, (e) defining and naming themes, and ( $f$ ) producing the report. Data interpretation and discussion were based on the theoretical framework derived from the existing literature.

\section{Results and Discussion}

The reports from participants were grouped into three thematic categories: "Social experiences of acceptance and respect", "Discrimination and prejudice in their (almost) imperceptible nuances", and "Fighting for rights and visibility".

\section{Social Experiences of Acceptance and Respect}

The couples stated repeatedly that they had not been subjected to prejudice and discrimination for being homosexuals or because of their samesex family and that they were treated with respect in most places. Adriana and Tarsila stated that they had never experienced prejudice. However, Adriana mentioned the society's depreciative views on homosexuality, as shown below:

Most places we go, the different ambience and atmosphere, everybody respects us, regardless of [...] most people know about our relationship and it's natural. [...] So, like, I've never been misserved, discriminated against, or mistreated because of that, nothing. [...] That is why I say that, from 
What I remember, since Nisia came, we've never experienced prejudice (Adriana).

We've never met someone who looked at us and said, "But how come? Two women and another child?" [...] / think it is because people do not see us as a family. I think that, to people, a family is formed after there is a child involved; then it is family, then there is respect (Tarsila).

I think that the majority of society thinks that a homosexual couple, using a derogatory term, likes bacchanal [...] it's all party, it's never ending fun; it does not appear to work [...] we stay three months with a person, breakup and start dating someone else. More conservative heterosexuals cannot understand that feeling and love between two people of the same sex is possible. [...] In my opinion, I don't think I've seen people looking down their noses at us saying something (Adriana).

Tarsila and Adriana's comments demonstrate that social tolerance coexists with the social invisibility of families formed by a lesbian couple. The lack of recognition of female-female couples seems to be due to different types of bias: on the one hand, since motherhood is often seen as natural in our society, women's desire to have children does not come as a shock (Uziel, 2007); on the other hand, this relationship becomes invisible due to reduction of eroticism between women, leading to invisibility of the couple (Meinerz, 2011).

Another participant, Isabelle, stated that wearing masculine-style clothing and having masculine physical traits prevent her from experiencing social prejudice. People do not realize that they are a female-female couple.

This is the benefit of dressing like a man; because if I had long hair and wore a skirt, it would be kind of weird to walk hand in hand with her [Beatriz] down the street and [...] prejudice would be much stronger. As for society, we haven't had serious problems because people generally do not realize that we're a gay couple, so that's fine. They say the "Mr" and the "Mrs" are over there (Isabelle).

Isabelle's comments also indicates a type of social invisibility that affects some same-sex couples when they (male/female) apparently meet the heteronormativity standards. The respondents' claims that they had not experienced direct prejudice attracted the researchers' attention, especially because of the way they described the situation. Due to the significant social repercussion of their family adoption case, another participating couple, Heitor and Pedro, described in detail some situations they experienced showing social visibility and acceptance of their family after media exposure.

People we do not even know ask us, "Hey, how are the girls doing?!" So, people know about our lives even without knowing us. [...] Then, we see that society has accepted us, and this is nice, right? (Heitor).

Once a woman from São Paulo called me and said: "Look, you do not know me, but I have a relative who lives in [name of the city where they live], and I'm sending a gift to your daughter". [...] She sent Adélia a pair of flip flops; I still don't know who this lady is [...] Thus, people have been nice (Pedro).

Due to the media exposure following the adoption, this couple acknowledged having received special social attention because they are famous, as if mediatization has granted them some "type of pardon" mitigating social prejudice:

When we go some places, we notice that people devote more attention to us. Sometimes, Adélia is even a little "spoiled", she's got some small gifts. In some places, I've seen people trying to let us cut in line, treating us a little better because of the media, because of the exposure. It seems like we're a TV stars, understand? (Heitor).

The data suggest that, gays and lesbians gain greater social acceptance when they meet some heteronormative standards. According to the literature, same-sex parents have a desire to be recognized as people like everybody else, and as such, they may want children at some point in the future (Goldberg \& Gartrell, 2014; Toledo, 2008). 


\section{Discrimination and Prejudice in their (Almost) Imperceptible Nuances}

\section{"That kind of look" [...] the person doesn't say anything, but [...] Mother of God, you can read it on their face".}

The participants mentioned the existence of indirect prejudice when they notice that some people get uncomfortable around them. Therefore, prejudice and discrimination in their many guises, even when they are subtle, affect the participants' daily lives (Almeida, 2012; Corrêa, 2012; Fleury \& Torres, 2007; Moscheta, 2004).

Heitor and Pedro stated that when they adopted their first child (a daughter) they believed they would encounter prejudice. They mentioned knowing about people who are against their family, but who do not openly express their opinion.

I confess that in the beginning, when I adopted Adélia, I thought I would encounter obstacles in the community, someone would approach me and say, "Oh, this is an absurd", and that I would be called names, I really did. [...] But I've never face anything like this. [...] We know there are people who are against it, but nobody approaches us to speak their minds to our face, right? (Heitor).

Yeah, there might be, but they talk behind our back (Pedro).

Gay parenting seems to be seen differently by the couple and by others; in general, the couple image is strongly associated with promiscuity. When they become parents, the emphasis of the relationship, in their imaginary, shifts from erotic and sexual to caring. There is a feminization of these men (Uziel, 2009).

Candido reported that he has not encountered direct prejudice; however, he and his life partner, Francisco, have noticed when people give them a disapproving look, suggesting that their family is abnormal and does not have a traditional structure. Accordingly, it demonstrates that society has not yet fully accepted that a family can be formed by two men and a child.
Prejudice like people mistreating us, no! [...] but people looking down their noses at us, oh yes. [...] We don't walk hand in hand, right? [...] We always walk side by side. [...] People always give you dirty looks, you know? As if you are not normal [...] because there are two men walking with a child (Candido).

Anita stated that they have shown people that they are not different from anyone else. They believe that there is indirect prejudice, but they have never felt embarrassed.

"Ew! Check those dykes out, how horrible!" But, over time I think we have been showing we are not different from anyone else, we have our own problems, our debts, we work, we pay our bills, our taxes; we're doing our best to raise our son, you know? [...] They may talk behind our back, but to our face, we've never been embarrassed like that (Anita).

When people realize that they are lesbians, some accept it and others express prejudice through gestures or facial expressions that convey disapproval or disgust. "When they realize it, you feel it because of the look some people give you. But there are some others who just say, "oh, okay". [...] "That kind of look" the person doesn't say anything, but [...] Mother of God, you can read it on their face!" (Isabelle).

The respondents' reports demonstrate the situations in which subtle and "indirect" prejudice permeate the everyday lives of these families. Although they are not physical and aggressive expressions of homophobic violence, they are instances of prejudice and discrimination that reinforce the deviant status of homosexuals.

\section{Same-sex parenting: visibility and rights challenged by central institutions of society and everyday life}

Tarsila described an episode of discrimination. Since they were not seen as a couple, they were denied the right to join a private club under the family membership plan.

The strongest prejudice we've experienced was when we wanted to become members 
of [the club's name]. [...] And I come from a traditional family that is member of this club, so it was a shock to them. He [the club's membership representative] said, "Hey, as of today, you are club members, but I ask you to be careful and watch your behavior and attitudes". Then I said, "Whoa! Wait! It is not a gay couple who had sex in the pool, we're not a gay couple who make out in the ballroom [...] gays are very respectful because what we do within four walls depends only on us, we don't want anyone to see it". Then he replied: "No, but [...]". Because I think it needs to be said, they have to respect us [...] today, the heterosexuals are those who make out in the street, it is them and not us (Tarsila).

This belittling social perception of samesex couples corroborates some existing literature (Nascimento, Scorsolini-Comin, Fontaine, \& Santos, 2015). Prejudice manifestations are generally more subtle and are legitimized under current labor laws. Francisco reported an experience of discrimination in the workplace. The company where he works offers a "day care refund" benefit exclusively for women employees.

In fact, [name of company] offers a benefit of [...] which gives a reimbursement for child care that is big enough to enroll her in a private daycare center. But the company denied this benefit to me [...]. Because I'm a man; the company claimed that this a benefit offered exclusively for women employees (Francisco).

lone and Anita's civil wedding ceremony was publicized in the media. They commented in detail on the considerable repercussion of this event, pointing out prejudiced comments made by religious people on social networks.

I felt really annoyed with the internet comments regarding the wedding. [...] / said, most [comments] were made by evangelicals [...] they were disparaging and had highly offensive words. [...] This shocks me; how can people say things without knowing what they are taking about? (Ione)

It's very mean, you know? A person speaking like that; someone who is speaking in God's name, saying that our union is an aberration, it's against God's will, and that we should die in the hellfire, you know? How can people say that God's spirit live in their heart and yet wish someone so much harm? (Anita).

Pedro described a situation that took place in a television program in which he participated; there was a fierce debate between him and a catholic priest who was against adoption by samesex couples.

Once we participated in a television show; there was a priest and the show was live. [...] Then, the priest turns to me and says that the Catholic Church blesses the family formed by daddy, a mommy and little child, right? Then I said: "But what do you mean by that? That the Catholic Church condemns me for adopting a child who does not have my blood, to whom I give a home, I provide education, I give love, affection, attention, and you are saying that I am what? Is the Catholic Church against it? This would be similar to saying that you are disobeying the first precept of your Church, which is: "Love your neighbor as yourself", right? So, I don't know if these people think we have no culture [...] and they think they're dealing with "any given person"; that they are talking nonsense and we're going to accept it and say nothing. Then, when you start to challenge their remarks, they have nothing else to say (Pedro).

Once we were walking around the mall and a mother said, "But where is the mother of that child?". People have not yet accepted that a family can be formed by two men and a child [...], people stare. Extraterrestrial! [...] Because you love another man; it goes against all principles of the traditional family model. Because two men adopted a child; it goes against the principles of the traditional family model (Candido).

Based on these reports, it was observed that the relationship between same-sex couples and their families is established through an interrelationship with society, which often encourages prejudice 
and discrimination that constrain, condemn, and segregate the experiences of these individuals. Although it has been gaining recognition, adoption by same-sex couples still causes discomfort, embarrassment, and awe, and there is a great deal of doubt about their parenting skills (Rosa, Melo, Boris, \& Santos, 2016). Rios (2006) argued that it is necessary to consider "the relationship between democracy, social citizenship, human rights, and sexual rights, which are basic elements of a model of democratic understanding of sexual rights that will be proposed and which I call the democratic right of sexuality" (p.73). These are the ideas and concepts that led the participating couples to condemn prejudice against them and the lack of recognition of their social citizenship rights.

\section{Fighting for Rights and Visibility}

Tarsila and Adriana obtained legal recognition of their right to join a private club only through a lawsuit. The couple described their experience in detail:

Because I said I was going to fight and I did. When we won the lawsuit, they couldn't do anything, they had to give it to us. [...] When we signed the domestic partnership affidavit, the club did not accept it. Then, we had to sue them, so the club would recognize as a married couple. Because, at that time, marriage had not been legally recognized. Marriage happened later, so even in this respect we had to pave the way. Then, with Nisia, it got easier. [...] We filed a lawsuit (Tarsila).

We have the lawsuit for anything [...] let's suppose, health insurance, if they do not accept our contract, we have the lawsuit, which they have to accept. (Adriana)

We are not afraid, we fight for our rights. [...] Right is right, isn't it? You have to fight for them. And today, Nísia is a club member too (Tarsila).

Every place we go, hospital, doctors, therapy, there's a form we have to fill out, which has "father and mother". The first thing we say:
"Nísia does not have a father, she has two mothers". Then I cross out the word "father" and write "mother" instead. So, right from the beginning, people will know that Nisia is the daughter of [...] (Adriana).

As for civil marriage, Anita mentioned that they allowed media coverage so that they would "take the bull by the horn"; someone has to show that we are not different", and also because samesex unions are not made public by the couples themselves, which, according to them, hinders the fight for the rights of the LGBT population.

The only time that we as a family experienced this harassment, you know? [...] I think it was too much exposed [...] Because people nowadays want to have a same-sex union; they want to be respected; they want to enjoy their rights, but they do not want to take the bull by the horns. Well, it's easy to want something and not fight for something. This may not mean anything today, but someday it will mean a lot for some people [...] it was the first ceremony being held there because no one wants to take the bull by the horns. There had been 16 [same-sex] wedding ceremonies there, but everybody went there, got the license and left, got it? I told him I had no problem with that. [...] I was sure that we would be blasted, that the great majority of people would bad-mouth us, would excommunicate us, would curse us, do you understand? But someone has to start doing something. Someone has to take the bull by the horns; someone has to show that we are not different from them (Anita).

As previously mentioned, Francisco reported an experience of discrimination in the company where he works, which provides the "day care refund" benefit for women employees only. He has filed a lawsuit in the Labor Court, alleging discrimination, but it has not yet been resolved.

I had a hearing in the Labor Court challenging the company claim because the child has the right of this benefit, the child will benefit from it; because it is the child's benefit, 
not the employee's. It is discrimination [...] and this is what I'm trying to prove in court (Francisco).

In the study carried out by Lira, Morais, and Boris (2016), one of the great challenges of the same-sex parenting experience described by the participants concerns the social prejudice that still pervades their lives. Homophobia still affects the lives of lesbian parent families, and its manifestations can be found in private and public spheres. On the other hand, their study showed that the growing discussion about lesbian parenting, legal decisions about the same-sex parenting experience, the fight for recognition and legitimacy of lesbian women rights, and the enhancement of social support networks have contributed to demystify and break down prejudices that still permeate these relationships.

\section{Final Considerations}

Studies involving families formed by samesex couples raising children are important and valuable since they address a recent phenomenon that has still been little investigated in Brazil. Among the many arguments that have been put forward to defend or condemn the legitimacy of these families, is the prejudice against homosexuality, which is still prevalent in our society.

The men and women interviewed attributed particular meanings to their experiences of being same-sex parents. They assumed their social role as they managed to develop their own conjugality and parental projects in the struggle within a social context permeated by the hegemony of heteronormative values that guide family practices and relationships. The prejudices experienced by the participants in this study were related to their lifestyle and their audacity of becoming parents, challenging social norms and gender stereotypes. Experiences of prejudice and intolerance were identified in their everyday lives. However, it was also found that attitudes of willingness and perseverance in their fight for their rights, exposure to mass media - proved to be protective measures against prejudice and social intolerance.

Families formed by same-sex couples are part of the increasing diversity of families in our society. Emphasizing the difference related to being a same-sex couple can be a visibility strategy, but there is a risk of highlighting differences that do not seem to affect the everyday life.

The discussion about same-sex parenting contributes to the expansion of the concept of family and to the diversification of studies on homosexuality. If a few years ago the combination between family and homosexuality was unthinkable, difficult, or even hidden, or took place with innumerable reservations, today it is a reality and it illuminates many possibilities within a research field.

Academic and professional training in Psychology, Law, Social Work, and Pedagogy, among other related fields, do not fully address this issue. We hope that the present study and other further studies related to this topic can generate knowledge to confirm and support previously reported results and stimulate ideation and the development of policies and strategies to promote social citizenship and respect for diversity. Furthermore, it is absolutely essential to encourage the implementation of preventive measures to support these individuals and their families and prevent homophobic violence. A limited number of studies have addressed prejudice and discrimination against Brazilian same-sex families; therefore, this topic deserves special attention. The dissemination and scientific exchange in this field, based on the prerogatives of a plural society, should contribute to deeper reflections upon changing prejudicial and exclusionary attitudes towards the development and multiplicity of family arrangements nowadays.

\section{Contributors}

M.A. TOMBOLATO contributed to the conception of this study and to the development of the theoretical framework and methodological design, manuscript writing, data collection, analysis and interpretation, and critical revision and approval of the final version. 
A.C.B. MAIA contributed to the development of the theoretical framework and methodological design of this study and to data interpretation and critical revision and approval of the final version. A.P. UZIEL contributed to the development of the theoretical framework and methodological design of this study and to data interpretation and critical revision and approval of the final version. M.A. SANTOS contributed to the development of the theoretical framework and methodological design of this study and to manuscript writing, data analysis and interpretation, and critical revision and approval of the final version.

\section{References}

Almeida, M. R. (2012). Os processos subjetivos no acolhimento e na adoção de crianças por casal homoafetivo: um estudo de caso (Tese de doutorado não-publicada). Universidade de São Paulo.

Ariès, P. (1986). História social da criança e da família (2a ed.). Rio de Janeiro: Guanabara.

Badinter, E. (1985). Um amor conquistado: o mito do amor materno. Rio de Janeiro: Nova Fronteira.

Biernacki, P., \& Waldorf, D. (1981). Snowball sampling: Problems and techniques of chain referral sampling. Sociological Methods and Research, 10(2), 141-163.

Bogdan, R., \& Biklen, S. (1994). Investigação qualitativa em educação: uma introdução à teoria e aos métodos. Porto: Porto Editora.

Borrillo, D. (2009) Homofobia, silêncio e naturalização: por uma narrativa da diversidade sexual. In T. Lionço \& D. Diniz (Orgs.), Homofobia e educação: um desafio ao silêncio. Brasília: Letras Livres.

Braun, V., \& Clarke, V. (2006). Using thematic analysis in psychology. Qualitative Research in Psychology, 3(2), 77-101.

Corrêa, M. E. C. (2012). Duas mães? Mulheres lésbicas e maternidade (Tese de doutorado não-publicada). Universidade de São Paulo.

Farias, M. O., \& Maia, A. C. B. (2009). Adoção por homossexuais: a familia homoparental sob o olhar da Psicologia Jurídica. Curitiba: Juruá.

Fleury, A. R. D., \& Torres, A. R. R. (2007). Análise psicossocial do preconceito contra homossexuais. Estudos de Psicologia (Campinas), 24(4), 475-486. https:// dx.doi.org/10.1590/S0103-166x2007000400007

Goldberg, A. E., \& Gartrell, N. K. (2014). LGB-parent families: The current state of the research and directions for the future. Advances in Child Development and Behavior, 46, 57-88.

Golombok, S. (2015). Modern families: Parents and children in new family forms. Cambridge, UK: Cambridge University Press.
Golombok, S., Mellish, L., Jennings, S., Casey, P., Tasker, F., \& Lamb, M. E. (2014). Adoptive gay father families: Parent-child relationship and children's psychological adjustment. Child Development, 85(2), 456-468.

Grossi, M. P., Uziel, A. P., \& Mello, L. (Orgs.). (2007). Conjugalidades, parentalidades e identidades lésbicas, gays e travestis. Rio de Janeiro: Garamond.

Lira, A. N., Morais, N. A., \& Boris, G. D. J. B. (2016). (In) visibilidade da vivência homoparental feminina: entre preconceitos e superações. Psicologia: Ciência e Profissão, 36(1), 20-33.

Martinez, A. L. M., \& Barbieri, V. (2011). A experiência da maternidade em uma família homoafetiva feminina. Estudos de Psicologia (Campinas), 28(2), 175-185. https://dxdoi.org/10.1590/50103-16 6x20110002000005

Meinerz, N. E. (2011). Entre mulheres: etnografia sobre relações homoeróticas femininas em segmentos médios urbanos na cidade de Porto Alegre. Rio de Janeiro: EdUERJ.

Minayo, M. C. S. (Org.). (2010). Pesquisa social: teoria, método e criatividade (29a ed.). Petrópolis: Vozes.

Ministério da Saúde (Brasil). (2012). Resolução n 466, de 12 de dezembro de 2012 do Conselho Nacional de Saúde/MS. Recuperado em abril 22, 2012, de http:// conselho.saude.gov.br/resolucoes/2012/Reso466.pdf

Moscheta, M. S. (2004). Construindo a diferença: a intimidade conjugal em casais de homens homossexuais (Dissertação de mestrado não-publicada). Universidade de São Paulo, Ribeirão Preto.

Nascimento, G. C. M., Scorsolini-Comin, F., Fontaine, A. M. G. V., \& Santos, M. A. (2015). Relacionamentos amorosos e homossexualidade: revisão integrativa da literatura. Temas em Psicologia, 23(3), 547-563.

Oliveira, D. B. B. (2011). Familias contemporâneas: as voltas que o mundo dá e o reconhecimento jurídico da homoparentalidade. Curitiba: Juruá.

Rios, R. R. (2006). Para um direito democrático da sexualidade. Horizontes Antropológicos, 12(26), 71-100.

Rodriguez, B. C. (2012). A representação parental de casais homossexuais masculinos (Dissertação de mestrado não-publicada). Universidade de São Paulo.

Rosa, J. M., Melo, A. K., Boris, G. D. J. B., \& Santos, M. A. (2016). A construção dos papéis parentais em casais homoafetivos adotantes. Psicologia: Ciência e Profissão, 36(1), 210-223.

Roudinesco, E. (2003). A família em desordem. Rio de Janeiro: Jorge Zahar.

Secretaria de Direitos Humanos (Brasil). (2012). Relatório sobre violência homofóbica no Brasil: ano de 2011. Brasília: Autor. Recuperado em 2014-10-14, de http:// www.sdh.gov.br/assuntos/lgbt/pdf/relatorio-violenciahomofobica-2011-1 
Secretaria de Direitos Humanos (Brasil). (2013). Relatório sobre violência homofóbica no Brasil: ano de 2012. Brasília: Autor. Recuperado em outubro 14, 2014, de http://www.sdh.gov.br/assuntos/lgbt/pdf/relatorioviolencia-homofobica-ano-2012

Supremo Tribunal Federal (Brasil). (2013). Resolução sobre casamento civil entre pessoas do mesmo sexo é aprovada pelo Conselho Nacional de Justiça. Brasília: Autor. Recuperado em novembro 27, 2013, de www2.stf.jus.br/portalStflnternacional/cms/destaques Newsletter.php?sigla=newsletterPortallnternacional Destaques\&idConteudo $=238515$

Toledo, L. C. (2008). A família no discurso dos membros de famílias homoparentais (Tese de doutorado não-publicada). Universidade de São Paulo.
Uziel, A. P. (2007). Homossexualidade e adoção. Rio de Janeiro: Garamond.

Uziel, A. P. (2009). Homossexualidades e formação familiar no Brasil contemporâneo. Revista Latinoamericana de Estudios de Familia, 1, 1-12.

Vieira, R. S. (2011). Homoparentalidade: estudo psicanalítico sobre papéis e funções parentais em casais homossexuais com filhos (Dissertação de mestrado não-publicada). Universidade de São Paulo.

Zambrano, E. (2006). O direito à homoparentalidade: cartilha sobre as familias constituídas por pais homossexuais. Porto Alegre: Vênus.

Received: June 20, 2016

Approved: March 7, 2017 